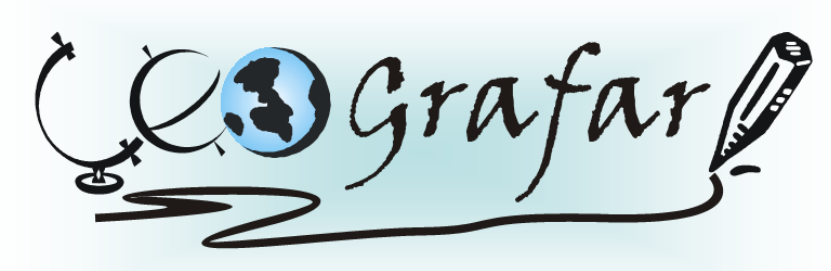

Revista Eletrônica do Programa de Pós-Graduação em Geografia - UFPR

\title{
PROPOSTAS DE DESENVOLVIMENTO DO AGRONEGÓCIO: SUBALTERNIDADE E DOMINAÇÃO.
}

\author{
ROBERTA OLIVEIRA DA FONSECA ${ }^{1}$
}

\begin{abstract}
RESUMO
O presente artigo procura apresentar os argumentos utilizados pelas entidades representantes do agronegócio brasileiro na defesa de seu modelo de desenvolvimento territorial, contrapondo-se a visão da academia, quando revela a fragilidade destes argumentos. Exemplifica-se o modelo de desenvolvimento territorial do agronegócio canavieiro no recorte espacial do Pontal do Paranapanema evidenciando-se os interesses do grande capital nesta região sabidamente palco de conflitos e luta pela terra.
\end{abstract}

Palavras-chaves: agronegócio, expropriação, subalternidade, cadeia produtiva.

\section{PROPOSED DEVELOPMENT AGRIBUSINESS: SUBALTERNITY AND DOMINATION}

\begin{abstract}
The article presents to arguments made by representatives of agribusiness entities in the defense of territorial development model, in contrast with the vision of the academy, when it reveals fragility of these arguments. Exemplifies the model of territorial development of the sugar cane agribusiness in spatial area of Pontal evidencing interests of big business in this region known history of conflict and struggle for land.
\end{abstract}

Keywords: agribusiness, expropriation, subordination, production chain.

\footnotetext{
${ }^{1}$ Aluna do $2^{\circ}$ ano do curso de Geografia da FCT/Unesp (2011); Membro do Grupo de Estudos Dinâmica; Regional e Agropecuária (Gedra). E-mail: roliveirafonseca@bol.com.br
} 


\section{INTRODUÇÃO}

A presença constante de propagandas ressaltando a participação do agronegócio brasileiro na balança comercial do país evidencia a grande necessidade de se compreender o discurso utilizado pelos representantes e defensores do setor, conhecendo seus argumentos e justificativas quando divulgam o modelo de desenvolvimento territorial pensado sob a lógica capitalista. Elencando as principais entidades do agronegócio brasileiro, entre elas: Associação Brasileira do Agronegócio (ABAG), Confederação da Agricultura e Pecuária do Brasil (CNA), União da Indústria de Cana de açúcar (ÚNICA), Associação Brasileira de Produtores de Algodão (ABRAPA), o Conselho Nacional do Café (CNC) e a União Democrática Ruralista (UDR), destacam-se sucintamente suas trajetórias, a forma de organização e representatividade dentro do setor, bem como o discurso empregado por elas. Partindo ainda dos dois paradigmas norteadores: o da questão agrária na obra de Karl Kautsky (1986) e do capitalismo agrário na obra de Ricardo Abramovay (1992).

No que tange a desconstrução dos argumentos dessas entidades, apresentam-se algumas das inúmeras contribuições da academia, desmistificando as vantagens produtivas do agronegócio, apresentando seu caráter dominador, centralizador, sobretudo subalternizante, se valendo do grande latifúndio e da incorporação eficaz de novas tecnologias.

Dentre este quadro de discussões é que se pretende desenvolver este artigo; trabalhado a partir dos questionamentos suscitados na disciplina Desenvolvimento Territorial Rural e Questão Agrária ministrada no curso de graduação em Geografia da Faculdade de Ciências e Tecnologia da Universidade Estadual Paulista "Júlio de Mesquita Filho", Campus de Presidente Prudente. Para a obtenção de tal objetivo foi realizada revisão bibliográfica e levantamento de informações nos sites e documentos divulgados pelas entidades estudadas.

O presente artigo está organizado em duas seções, além desta introdução. Na primeira seção buscou-se apresentar os argumentos de defesa do agronegócio por meio de suas principais entidades representantes. O mesmo propósito terá a seção seguinte, porém em relação aos acadêmicos que estudaram ou estudam o setor; remetendo ao desenvolvimento territorial do agronegócio canavieiro no recorte espacial do Pontal do Paranapanema. Finalmente, destacou-se nas considerações finais a fragilidade dos argumentos do agronegócio e a necessidade de resistência 
da pequena propriedade e da agricultura familiar aos ataques do capital agroindustrial.

\section{OS TERRITÓRIOS DO AGRONEGÓCIO: SEGUNDO SUAS PRÓPRIAS CONCEPÇÕES}

O modelo de desenvolvimento hegemônico do campo brasileiro, adotado pelo Estado nas esferas federal, estadual e municipal, privilegia o modelo agroexportador, apostando dessa forma no denominado agribusiness ou na forma aportuguesada de agronegócio. A concepção apresentada pelos defensores deste setor, presente de forma maciça na economia mundial, vincula-se, sobretudo à idéia de controle eficiente das cadeias de produção agropecuária. As concepções apresentadas logo mais, são das duas principais entidades representativas do agribusiness no Brasil: ABAG (Associação Brasileira do Agronegócio) e CNA (Confederação da Agricultura e Pecuária do Brasil).

Segundo Rossi (2011) o agronegócio brasileiro é estratégico para a consolidação econômica do país: representa hoje $26,4 \%$ do PIB nacional, garante $36 \%$ das nossas exportações e responde por 39\% dos empregos gerados no mercado interno. É um setor indispensável, sinônimo de liderança na produção de alimentos para o mundo ${ }^{2}$.

Esses territórios tão bem definidos pelos partidários dessa visão de desenvolvimento estão muito bem "amarrados" ao discurso de entidades como a ABAG (Associação Brasileira do Agronegócio), que se apresenta com a missão de sensibilizar os segmentos decisórios do país para a importância do setor e de todas as suas cadeias produtivas para o desenvolvimento econômico e social do Brasil, desta maneira territorializa-se buscando congregar organizações e entidades representativas de todos os seus segmentos, desde os insumos para a agricultura e a produção animal até a chegada do produto ao consumidor, passando por pesquisa, produção rural, agroindústria, transporte, armazenamento, distribuição, comercialização, exportação e serviços de todas as naturezas. Atualmente a ABAG possui 62 Associadas Mantenedoras, que são as empresas e organizações representativas das cadeias produtivas do agronegócio, conta ainda com a

\footnotetext{
2 Rossi, Wagner. Palavra do ministro. http://www.agricultura.gov.br/ministerio
} 
assessoria de um Conselho Consultivo composto por 34 entidades do agronegócio.

Como podemos perceber o controle é absoluto, toda cadeia produtiva está organizada em grandes complexos agroindustriais, sobretudo com a incorporação de capitais transnacionais, que demandam grandes extensões de terra para produção de commodities como a soja e o algodão.

No 9ํㅡㄹ Congresso Brasileiro de Agronegócio, promovido pela ABAG ainda no ano de 2010, as denominadas Metas do Agronegócio no horizonte 2010/2020, também elencadas no dossiê das propostas aos presidenciáveis, sobretudo aos candidatos Dilma Rousseff do Partido dos Trabalhadores (PT) e José Serra do Partido da Social Democracia Brasileira (PSDB). Incluíam as seguintes premissas: um aumento de 37\% na produção de grãos (arroz, feijão, milho, soja e trigo), passando de 140 milhões para 180 milhões de toneladas; outros panoramas ainda foram apresentados, como a agroenergia que contará segundo as estimativas do setor com $20 \%$ de participação na matriz energética nacional,assim como a incorporação de 15 milhões de hectares de áreas degradadas no processo produtivo, além de dobrar o valor das exportações para U\$\$ 130 bilhões e a incorporação de 800 mil pequenos produtores ao mercado. ( $9^{\circ}$ CONGRESSO BRASILEIRO DE AGRIBUSINESS, 2010).

Além da ABAG, as propostas da CNA (Confederação da Agricultura e Pecuária do Brasil) comportam o mesmo intuito, congregando associações, lideranças políticas e rurais em todo o país. Também apóia a geração de novas tecnologias e a criação de agroindústrias responsáveis por aumentar a produtividade rural. Outra iniciativa da entidade é a cooperação e apoio aos programas regionais de desenvolvimento agrícola, segundo seus articuladores; aqueles que se destinam a reduzir as desigualdades geoeconômicas em todos os Estados brasileiros.

O Sistema CNA abrange quatro entidades: o Canal do Produtor (informações e serviços), a CNA (representação e defesa dos interesses dos produtores rurais), o Instituto CNA (programas sociais) e o SENAR (aprendizado rural). ${ }^{3}$

As propostas vinculadas às entidades que representam 0 agronegócio nacional tomam sempre como discurso principal a defesa dos interesses do país atrelada a uma promessa de desenvolvimento econômico e social, para tanto

\footnotetext{
${ }^{3}$ Ver sobre Sistema-CNA em: http://www.canaldoprodutor.com.br/sobre-sistema-cna/sistema-cna
} 
apresentam como trunfo suas exportações que marcam sempre presença positiva na balança comercial. Assim buscamos apenas sublinhar algumas características do que entendemos como territórios do agronegócio apresentado na perspectiva dos mesmos.

\title{
2.1 TRABALHANDO COM DOIS MODELOS PARADIGMÁTICOS DE DESENVOLVIMENTO TERRITORIAL RURAL: QUESTÃO AGRÁRIA E CAPITALISMO AGRÁRIO
}

Os dois modelos paradigmáticos selecionados para observarmos a problemática do desenvolvimento territorial rural: Questão Agrária e Capitalismo Agrário, escritos respectivamente nos séculos $X I X$ e $X X$, são de fundamental importância na compreensão da realidade do campo, seus agentes sociais e processos, considerando a contribuição de cada obra em seu pioneirismo. Buscamos aportar a discussão de ambos paradigmas na obra de Karl Kautsky (1986) e Ricardo Abramovay (1992).

No livro Questão Agrária Kautsky (1986) elucida as desigualdades geradas pelo capitalismo, sobretudo na produção agrícola; para tanto se apóia no livro $\mathrm{O}$ Capital de Karl Marx, elencando os fundamentos trabalhados por este como: o valor, a mais-valia, o lucro e a renda da terra. Aponta entre outros fatores a superioridade dos grandes estabelecimentos agrícolas em detrimento do pequeno, discorrendo sobre as vantagens técnicas do primeiro:

\begin{abstract}
Todos sabem e é perfeitamente explicável que o pequeno estabelecimento se ressinta do peso excepcional de suas despesas de construção, manutenção dos animais de tração e do custo do inventário morto, bem como do custo de manutenção decorrente, por exemplo, da calefação e da iluminação. Essas despesas são relativamente bem maiores que as do grande estabelecimento. É inerente à natureza de certos procedimentos ligados à agricultura que estes apenas produzam bons resultados quando desenvolvidos em bases quantitativas bem amplas. Isso sucede com a criação de animais, com a execução de melhoramentos etc. Nesses domínios o grande estabelecimento mostra-se superior ao pequeno. [...] (KREMER apud KAUTSKY, 1986, p.99)
\end{abstract}

Kautsky (1986) entende que a reprodução do campesinato era resultado de um processo de autoexploração que se aproximava da barbárie. A presença do camponês no campo significava o atraso econômico e social presente neste meio.

O pequeno camponês proprietário ou arrendatário cultivando seu pedaço de 
terra é ainda proprietário de seus meios de trabalho, representa assim um vestígio de um modo de produção próprio de épocas passadas. Apesar de estar livre dos tributos e da corvéia feudal é dono da terra que cultiva. Porém, entende Kautsky que o seu fim está próximo, pois a essência do desenvolvimento do capitalismo no campo consiste na produção de duas classes sociais antagônicas: o proletariado e a burguesia. (FELICIO, 2006, p.22)

Kautsky (1986) propõe a implantação do socialismo através da instalação das cooperativas, transformando o camponês numa espécie de proletariado.

\footnotetext{
Mais para a agricultura que para a indústria, no entanto, as cooperativas se configuram como instrumento vigoroso a serviço do desenvolvimento econômico e para transição do pequeno para o grande estabelecimento. É por essa razão que se deve preferi-las ao invés do meio capitalista propriamente dito de promoção desse desenvolvimento: a expropriação da pequena propriedade. (KAUTSKY, 1986, p.359)
}

A produção cientifica de Kautsky, portanto pertence ao arcabouço teórico marxista para quais os camponeses não se constituem como sujeitos políticos que pudessem contribuir na sociedade socialista por estarem destituídos de conteúdo revolucionário quer em suas concepções, quer em suas manifestações.

Já o paradigma do Capitalismo Agrário, apresentado por Abramovay (1992) em seu livro Paradigma do Capitalsmo Agrário em Questão, entende que não existe uma discussão especifica sobre o campesinato e a questão agrária nas obras de Marx, Lênin e Kautsky. Elas não são as obras mais indicadas para quem quer conhecer e compreender a questão agrária e suas dimensões, vez que, por intermédio delas, é impossível definir de forma cristalina a natureza e a origem dos rendimentos camponeses, pois "a atividade produtiva que dá origem a sua reprodução não tem o estatuto de trabalho social e é neste sentido que o campesinato só pode se constituir naquele grupo de bárbaros de que falava Marx". (ABRAMOVAY, 1992, p. 36)

Afirma ainda que o mercado é o elemento de mediação e compreensão das relações sociais interessando apenas a produção da mercadoria, elegendo, portanto, critério predominantemente econômico "no qual a natureza dos mercados é um dos atributos microeconômicos mais reveladores da vida social". (Idem, p.104)

Abramovay (1992) diz que o camponês possui cultura e economia incompleta, parcial, impossibilitando sua participação em mercados completos desenvolvidos 
pela economia capitalista. Para este o camponês é a melhor definição de resto feudal, um resquício, classe que representa barbárie, um estorvo, uma vez que "as sociedades camponesas são incompatíveis com o ambiente econômico onde imperam relações claramente mercantis". (Idem, p.130)

Abramovay é adepto de que o final do camponês é sua extinção, pois o agricultor familiar é um novo personagem diferente do camponês tradicional, que teria assumido sua condição de produtor moderno totalmente integrado ao mercado racionalizando ao máximo sua produção.

\subsection{O QUE É O AGRONEGÓCIO?}

Cavalcante e Fernandes (2008, p.20) apresentam a noção de agronegócio formulada pelos economistas da Universidade de Harvard, John H. Davis e Ray A. Goldberg (1957). Segundo eles o agronegócio envolve um complexo de compra e distribuição de suprimentos agrícolas, a produção, o armazenamento, o processamento e a distribuição dos produtos acabados. Salientam ainda que tal empreendimento seja fruto do avanço técnico-científico e da disponibilidade de grandes extensões de terras naquele país; sendo a produção intensificada pela política de ajuda internacional dos Estados Unidos aos países arruinados na Segunda Grande Guerra. Depois da aprovação naquele país da Lei n 480 de 1954 que institucionalizou a ajuda aos países europeus, um grande fluxo de alimentos sem precedentes foi destinado a eles, com pagamento dos produtos em longo prazo e juros baixos.

Já Padilha Júnior (2006, p.3) apresenta além do conceito de Davis e Goldberg (1957), o da escola industrial francesa da década de 1960, ambas vertentes metodológicas defasadas quanto ao tempo e ao local de origem, mas que guardam em si pontos em comum. Aponta que Goldberg ao utilizar em 1968 a noção de commodity system approach (Cadeia de Produção Agro-Industrial) para estudar o comportamento dos sistemas de produção da laranja, do trigo e da soja nos Estados Unidos obteve sucesso pela aparente simplicidade e coerência do aparato teórico, bem como o seu grande grau de acerto nas previsões.

A Analyse de Filières (ou Cadeias de Produção) pode ser segmentada, de antes da porteira (insumos) até depois da porteira (comercialização) em três 
macrossegmentos, porém em muitos casos práticos os limites desta divisão não são facilmente identificáveis, além disso, essa divisão pode variar muito segundo o tipo de produto e o objetivo da análise:

A. Comercialização: representa as empresas que estão em contato com o cliente final da cadeia de produção e que viabilizam o consumo e o comércio dos produtos finais (supermercados, mercearias, restaurantes, cantinas, etc.). Podem ser incluídas neste macrossegmento as empresas responsáveis somente pela logística de distribuição.

B. Industrialização: representa as firmas responsáveis pela transformação das matérias-primas em produtos finais destinados ao consumidor. O consumidor pode ser uma unidade familiar ou outra agroindústria.

C. Produção de matérias-primas: reúne as firmas que fornecem as matériasprimas iniciais para que outras empresas avancem no processo de produção do produto final (agricultura, pecuária, piscicultura etc.). ${ }^{4}$

Assim o conceito de agronegócio incorpora uma gama de relações poderosas que dão uma nova roupagem para a incorporação de processos industriais associados à produção agrícola, mas que na verdade se preocupam em vender a imagem da modernização como sinônimo de desenvolvimento, atendendo aos interesses das grandes empresas capitalistas do setor.

\begin{abstract}
A idéia de ser um setor que interliga diversos segmentos da economia leva o agronegócio a se considerar um "supersetor", pois dentro e fora da porteira desenvolvem-se uma série de dinâmicas intercaladas entre os vários segmentos produtivos ligados à reprodução do setor. Desse modo, o resultado prático das estratégias do capital no setor agropecuário pode ser percebido, por exemplo, quando se analisa a constante presença na imprensa de notícias sobre os recordes de produção e de exportação de produtos agropecuários no Brasil.(BEZERRA, 2009, p.119)
\end{abstract}

Fernandes (2006, p.1) afirma que a imagem do agronegócio foi construída para renovar a imagem da agricultura capitalista, para "modernizá-la". É uma tentativa de ocultar o caráter concentrador, predador, expropriatório e excludente para dar relevância somente ao caráter produtivista, destacando o aumento da produção, da riqueza e das novas tecnologias.

\footnotetext{
${ }^{4}$ Ibid., p. 4-5.
} 
O território do agronegócio se fundamenta na integração corporativa dos produtores liderada pelas empresas que reconfiguram o espaço em função da lógica produtiva. Ao passo que as empresas se unem para defender seus interesses junto ao Estado, inserindo seus interesses no orçamento público, elas realizam um uso competitivo e, ao mesmo tempo, integrado, do território implantando infraestruturas e engendrando estratégias de ampliação do controle do mercado. $O$ estabelecimento deste complexo produtivo no espaço tendencia ao que Milton Santos (2004) chama de monofuncionalidade do uso da terra e das infraestruturas de transportes, negando a possibilidade de uso plural do espaço. (CAVALCANTE E FERNANDES, 2008)

Desde os primeiros estudos da expansão das fronteiras agrícolas no Brasil foi normal encontrar casos de produtores, que venderam suas propriedades nas áreas produtivas e compraram maiores extensões de terras nas frentes pioneiras.

Desta maneira, compreender as origens do conceito de agronegócio possibilita reunir subsídios que permitam identificar os conflitos que esse "supersetor" mascara ao tentar retratar apenas sua eficiência e rentabilidade à população, escondendo suas amarras e bifurcações.

\subsection{ELES POR ELES: O DESENVOLVIMENTO TERRITORIAL DO AGRONEGÓCIO NA VISÃO DE SUAS PRINCIPAIS ORGANIZAÇÕES REPRESENTATIVAS}

Para vislumbrar o desenvolvimento territorial pensado pelos agentes, atores e entidades que representam o agronegócio brasileiro, elencamos quatro organizações que entendemos possuir uma retórica substancial na influência das decisões dos segmentos no qual se inserem. Entre elas enquadram-se: a ÚNICA (União da Indústria de Cana-de-açúcar), a ABRAPA (Associação Brasileira de Produtores de Algodão), o CNC (Conselho Nacional do Café) e a UDR (União Democrática Ruralista).

A ÚNICA foi fundada em 1997, após a desregulamentação do setor sucroalcooleiro, ao longo dos anos 1990; é oriunda da Associação das Indústrias de Açúcar e Álcool do Estado de São Paulo (AIAA); seus interesses sempre buscaram solucionar o histórico problema da representação do setor, com questões tão heterogêneas como as que existem na cadeia produtiva sucroalcooleira. 
Logo após sua criação houve uma dissidência, resultando na criação da Cepaal (Coligação das Entidades Produtoras de Açúcar e Álcool) mesmo assim seu poder de negociação foi mantido, arregimentando os recursos de poder mais relevantes do setor. Congregando as unidades industriais de menor custo de produção, transação e mais produtividade, além de serem as mais integradas verticalmente com as unidades, possuindo maior controle sobre os mercados internos e externos. (IGLÉCIAS, 2007, p.81-82)

Suas propostas de desenvolvimento territorial estão relacionadas à expansão do mercado do álcool e açúcar em diversas frentes, apoiando o governo federal na tomada de medidas para a derrubada de barreiras protecionistas no campo externo. Elenca como principal missão a luta pela "universalização da produção e uso do álcool combustível, para que o mesmo possa se tornar uma commodity ambiental".No que se refere ao açúcar advoga na tomada de medidas para a ampliação do mercado mundial - um dos mais protegidos - bem como na redução do apoio interno e eliminação dos subsídios à exportação.

Sob a premissa da sustentabilidade a Única criou um núcleo de Responsabilidade Socioambiental e Sustentabilidade com o objetivo de desenvolver macro-projetos focados na capacitação de funcionários e gestores, dentre eles estão fixados os seguintes: parceria com o Instituto Banco Mundial (World Bank Institute WBI); Projeto Tear em parceria com o FUMIN, Fundo Multilateral de Investimento do BID (Banco Interamericano de Desenvolvimento) e Instituto Ethos; assim como o indicador Ethos de Responsabilidade Sócio-empresarial e o Programa de elaboração do relatório de sustentabilidade GRI (Global Reporting Initiatives) ${ }^{5}$.

A criação da ABRAPA ocorre no ano de 1999, segundo informações da própria entidade, representa $96 \%$ de toda a área plantada com algodão, 99\% da produção e $100 \%$ da exportação no Brasil. Sua pedra fundamental foi a Associação Mato-Grossense de Produtores de Algodão (AMPA), composta na atualidade por nove associações estaduais (Mato-Grosso, Mato-Grosso do Sul, Goiás, São Paulo, Paraná, Minas Gerais, Bahia, Piauí e Maranhão). A missão da entidade é "representar os interesses da conicultura nacional (produção de algodão) junto às autoridades públicas e privada; promover a relação entre produtores, governo,

\footnotetext{
${ }^{5}$ Ver em http://www.unica.com.br/content/show.asp?
} 
comerciantes e indústria têxtil e a promoção do algodão brasileiro nos mercados internos e externos" ${ }^{\prime \prime}$.

Quanto ao desenvolvimento territorial recorrem ao que chamam de responsabilidade social e ambiental, criando o chamado Programa Socioambiental da Produção de Algodão (PSOAL) para fornecer orientação aos conicultores sobre legislação trabalhista e ambiental.

Já o CNC (Conselho Nacional do Café) teve sua fundação no ano de 1981, incorporando produtores, cooperativas, associações de cafeicultores e federações de agricultura de estados produtores. Apresenta como missão "a defesa e a promoção dos direitos e interesses dos produtores de cafés do Brasil em consonância com os princípios do desenvolvimento sustentável, consolidados em suas dimensões econômica, social e ambiental". Em seu Plano Diretor o CNC engloba o Código Comum para a Comunidade Cafeeira, lideradas pelo governo suíço, alemão, organizações européias, o PIC - Produção Integrada de Café; liderado pelo MAPA (Ministério da Agricultura, Pecuária e Abastecimento) e a EMBRAPA (Empresa Brasileira de Pesquisa Agropecuária). Comporta ainda em seu Estatuto Social o incentivo ao agronegócio cafeeiro como desenvolvimento territorial, visando aumentar a competitividade do setor alegando responsabilidade social na defesa e proteção do meio ambiente, do consumidor, à livre-concorrência e aos bens e direitos de valor histórico, turístico e paisagístico ${ }^{7}$.

A UDR (União Democrática Ruralista) teve sua primeira sede regional em 1985 na cidade de Presidente Prudente, estado de São Paulo; sua sede nacional é inaugurada em Brasília no ano 1986; é uma entidade de classe que reúne ruralistas de todo o país e tem como princípio fundamental a preservação ao direito da propriedade e a manutenção à ordem e as leis do país. A principal mobilização da UDR deu-se em torno da Constituição de 1988, incluindo Lei que preserva os direitos de propriedade rural em terras produtivas. No que se refere ao desenvolvimento territorial apoiado pela entidade, destaca-se a conservação da propriedade privada e a liberdade de produzir como direitos inalienáveis, mantendo

\footnotetext{
${ }^{6}$ Ver mais em: http://www.abrapa.com.br/institucional/Paginas/A-ABRAPA.aspx

${ }^{7}$ Ver mais em http://www.cncafe.com.br/galeria/00000191_ESTATUTO\%20CNC. doc
} 
para tanto fórum de estudos jurídicos voltados à formulação de política fundiária, incluindo a produção e o comércio da agropecuária e do agronegócio brasileiro ${ }^{8}$.

Um ponto comum na organização dessas entidades é a participação das mesmas na Rural Brasil (Conselho Superior da Agricultura e Pecuária do Brasil) que funciona no âmbito da CNA, apontada como uma arena para a comunhão de ideias e princípios, mas que no fundo não passa de uma instância na qual se organiza o grande lobby da agropecuária brasileira junto aos três poderes.

\subsection{AGRONEGÓCIO X AGRICULTURA FAMILIAR: O MODERNO E O ATRASADO?}

Segundo Gualda (2008) os argumentos quanto à impossibilidade de coexistência dos dois modelos distintos têm raízes históricas quanto à origem e desenvolvimento de cada um. Enquanto o primeiro apresenta-se como moderno e competitivo, surgido no âmbito da "Revolução Verde" da década de 1970, caracterizado por um pacote tecnológico e econômico que tinha como objetivo fortalecer e ampliar a dinâmica da acumulação capitalista no campo; o segundo emerge dos movimentos sociais do campo a partir de meados de 1990, capitaneados pelo sindicalismo rural ligado a Confederação Nacional dos Trabalhadores na Agricultura (CONTAG).

Diante da emergência de propiciar um tratamento diferenciado ao pequeno produtor rural, os dirigentes brasileiros optaram por tratar os dois modelos de forma distinta, institucionalizando tal separação através da criação de dois ministérios. Os interesses da agricultura familiar ficaram sob a responsabilidade do Ministério de Desenvolvimento Agrário, enquanto as demandas do setor agroexportador devem ser atendidas pelo Ministério da Agricultura, Pecuária e Abastecimento.

Dentre os conflitos colocados pelos defensores do modelo representado pela agricultura familiar está o fato de que em um país como o Brasil onde existem mais 44 milhões de pessoas vivendo abaixo da linha da pobreza não há espaço para implementação de políticas agrícolas que incentivam a exportação de alimentos.

Do outro lado, os representantes do setor agroexportador não concordam com políticas públicas diferenciadas em favor da agricultura familiar, pois veem nas mesmas apenas "mero paliativo para minorar os efeitos da "inevitável"

\footnotetext{
${ }^{8}$ Ver em: http://www.udr.org.br/objetivos.htm
} 
marginalização e exclusão dos pequenos agricultores sem condições reais de integração e competição nos mercados globalizados" (DENARDI, 2001, p. 58).

Ao se avaliar as vantagens da agricultura familiar sobre 0 modelo agroexportador, constata-se que além de possuir um caráter mais distributivo do ponto de vista social, apresenta práticas ambientais mais sustentáveis. Veiga (1998), ao defender diretrizes para uma nova política agrária que privilegie a agricultura familiar, mostra que esta forma de organização da produção agropecuária é superior ao modelo agroexportador em vários produtos. Argumenta, ainda, que se além da dimensão alocativa, a dimensão distributiva também estiver presente na avaliação da eficiência econômica, "a agricultura familiar brasileira mostra-se superior à patronal, apesar do desprezo de que foi vítima nos últimos 150 anos".

\subsection{DESENVOLVIMENTO DO AGRONEGÓCIO: SUBALTERNIDADE E DOMINAÇÃO.}

Para Dourado e Mesquita (2010, p.193) desde o seu "nascimento" enquanto colônia, o Brasil já assumiria um papel de produtor de commodities. Após cinco séculos, muitos dos ranços do Brasil Colônia ainda permanecem a incomodar ou, paradoxalmente, a justificar uma realidade que dilacera e mutila camponeses, indígenas, quilombolas e trabalhadores urbanos; desde o ciclo da cana-de-açúcar até o atual momento vivenciado pelo campo brasileiro, com a política de agrocombustíveis, a lógica produtiva sempre esteve pautada na produção "de dentro" para saciar os "de fora".

Esse modelo agroexportador relegou ao Brasil a condição de dependente das decisões tomadas nos países centrais do sistema econômico, produzindo para atender aos padrões de qualidade internacionais, "brigando" na OMC (Organização Mundial do Comércio) contra os subsídios que esses países dispõem aos seus produtores.

Os partidários do setor agroexportador salientam que o Brasil possui capacidade de resposta às demandas atuais por alimentos, com elevada eficiência produtiva, apontando o país como o produtor de importante cesta de produtos com mais baixo custo (açúcar, soja, carne bovina, álcool, milho etc.). Falam ainda de vantagens comparativas, como a disponibilidade de recursos naturais e os contínuos 
investimentos do setor público e privado em tecnologia e pesquisa.

Todo esse discurso é desmistificado por Oliveira e Stedile (2005, p.27) ao pontuarem sobre a maciça propaganda veiculada nos meios de comunicação, sobretudo grandes jornais e canais de televisão, que descrevem o modelo do agronegócio, como se ele fosse a salvação do Brasil, como se fosse o responsável pelo crescimento da nossa economia, pela salvação da política econômica, pela geração de empregos, por uma agricultura moderna e pela produção de alimentos. Quando se examinam a fundo os argumentos do setor, verifica-se uma inconsistência; vamos ao exemplo: quando se fala de sua participação no crescimento do PIB os propagandistas misturam agricultura e agroindústria para informar que o peso na economia aumenta $37 \%$, mas as atividades agrícolas propriamente ditas, de lavoura e pecuária, correspondem a apenas $12 \%$ de toda a produção nacional, ou seja, mesmo que a agricultura dobre o valor ou o volume de produção, sua influência na economia total é muito pequena.

Ainda há outros mitos sobre seus méritos, entre eles a responsabilidade pelo sucesso da indústria; nada mais fantasioso, pois no final da década de 1970 e início da década de 1980, no auge da agricultura subordinada á indústria e com fácil crédito para se expandir a lavoura, a indústria nacional de máquinas vendia aos agricultores ao redor de 65 mil tratores por ano. Passaram-se trinta anos, implantouse o agronegócio do neoliberalismo, a venda de máquinas em 2004, auge do sucesso apregoado, foi apenas de 37 mil unidades. (Ibid, p.27-28).

Para se denunciar as verdadeiras intenções do modelo de desenvolvimento territorial proposto pelo setor do agronegócio, tomando o Brasil como referência, é necessário compreendê-lo em sua lógica de funcionamento, realizando mesmo que de maneira simplificada uma análise de suas singularidades ou apropriações. Sabemos de antemão que o domínio do grande capital estrangeiro e de suas corporações na economia como um todo, também representa um novo modelo de dominação do capital sobre a agricultura, o que permite apurar certas características, como o controle do comércio agrícola pelos grandes grupos transnacionais, ou seja, o modelo econômico já era subordinado a essas empresas, no entanto o comércio de grãos ou o que eles chamam de commodities também passa a ser controlado por elas, tais como: a soja, o milho, o trigo, o algodão etc. são monopólicas e manipulam as bolsas de valores internacionais, impondo e 
controlando o preço desses produtos no mercado mundial.

Outra importante característica é o estimulo à implantação de grandes fazendas de 5 a 10 mil hectares, com alta tecnologia, mecanização, pouca mão-deobra, baixos salários, que por atuarem na monocultura e em grandes extensões de terras, conseguem produzir a baixos custos, com alta produtividade, dedicadas exclusivamente a produção para exportação.

Tratando ainda das características, observamos as mudanças que este modelo econômico vem propiciando a agroindústria, como a compra pelas grandes de várias pequenas e médias do setor, controlando a produção e concentrando em apenas alguns grupos econômicos; o segundo processo é o da desnacionalização, ou seja, as grandes empresas que compram as pequenas e médias ou mesmo grandes empresas brasileiras, são transnacionais. A terceira mudança é de seleção dos maiores produtores, pois antes o modelo integrava o maior número possível de pequenos agricultores, fornecedores de matérias-primas, visando aumentar a produção, mas agora quer manter apenas os maiores, aqueles que possuem mais capital, que consigam produzir a preços menores. (Ibid, 2005, p.30)

A destruição do papel do setor público agrícola também faz parte do pacote do agronegócio, pois em todo mundo o Estado tem papel fundamental no apoio à agricultura, porque os agricultores não têm controle sobre a produção, ela depende da natureza, o ciclo agrícola demora meses para produzir um produto, produzindo a mercadoria mais importante para a sociedade - o alimento. No chamado setor público agrícola, o estado, por meio dos governos, procura viabilizar os agricultores, com preços justos, armazenagem, silos, menos impostos, subsídios, créditos para a produção, assistência técnica, pesquisa agropecuária e até seguro.

Uma das mais polêmicas "bandeiras" do agronegócio é o do novo modelo tecnológico que o setor imprime, baseado nas técnicas da biotecnologia, que prega o aumento da produtividade por meio de novas e melhores plantas, com técnicas desenvolvidas em laboratório para identificar quais genes que determinam as características mais produtivas de cada espécie e assim procurar desenvolver mais esses genes. Acontece que a biotecnologia não é mais controlada pelo Estado e sim por alguns grupos econômicos, que usam essa tecnologia para manter o agricultor cativo de suas sementes e variedades.

modelo de desenvolvimento territorial do agronegócio privilegia, portanto os 
grandes empresários e as transnacionais do setor ou que se associam a ele; mantendo trabalhadores e população na subalternidade, agindo para dominar e submeter os territórios as demandas do grande capital internacional.

\section{A MODERNIZAÇÃO DA AGRICULTURA NO ESTADO DE SÃO PAULO: UM PEQUENO PANORAMA...}

No inicio do século $X X$ algumas experiências modernizantes da agricultura no Estado de São Paulo são atribuídas a Carlos Botelho, dono da Fazenda Lobo, e a Antônio Luiz dos Santos Werneck, dono da Fazenda Banharão, que se situam respectivamente nos municípios de São Carlos e Bauru. Essas experiências consistiram no abandono da foice e da enxada, adotando-se máquinas para arar a terra. As mudanças ocorrem nas fazendas Lobo e Banharão após uma viagem realizada por Botelho aos Estados Unidos para conhecer a agricultura praticada naquele país.

No governo de Jorge Tibiriçá (1904-1908) Carlos Botelho assume a pasta da Secretaria da Agricultura no Estado de São Paulo, sob a orientação deste secretario a Sociedade Paulista de Agricultura - SPA - que editava a Revista Agrícola, assume o controle da política cafeeira, ou seja, temos um novo grupo no poder, uma fração da classe dominante, que representa o grande capital cafeeiro, de tendências modernizantes.

A proposta da Secretaria da Agricultura incluía a utilização de maquinário agrícola, combate ao desgaste do solo, diversificação da agricultura, política de formação de colônias agrícolas com subvenção estatal como forma de fixar os trabalhadores nas proximidades das fazendas, ensino agrícola, substituição de importações e expansão da rede ferroviária.

Apenas alguns objetivos foram efetivados, como: a distribuição de mudas e sementes, sendo a maior parte importada; a disponibilização de informações aos agricultores através do Boletim da Agricultura; Campos de experiência e demonstração do Instituto Agronômico de Campinas; o Horto Agrário Tropical em Cubatão; um Horto Botânico que produzia e distribuía mudas de plantas exóticas; o Posto Zootécnico Central; Serviço Meteorológico e a Galeria de Máquinas no Largo São Francisco. (FERRARO, 2005, p.47-67) 
Soares Oliveira (2009, p.30) aponta que o complexo cafeeiro participou do desenvolvimento do mercado de trabalho, bem como da constituição do mercado consumidor nacional. A partir de então, a própria agricultura brasileira passou a apresentar uma dinâmica produtiva voltada para o mercado interno, muito embora as transformações de sua base técnica ainda permanecessem atreladas ao mercado externo, ou seja, a sua modernização ainda dependia da importação de máquinas e insumos.

De modo geral a conjuntura econômica internacional apresentada no período pós-Segunda Guerra Mundial favoreceu a territorialização de empresas estrangeiras nos países da periferia do sistema capitalista, contribuindo assim para o processo de industrialização a exemplo do Brasil nos anos 1950/60. No campo, a influência do paradigma da Revolução Verde, incentivou a produção voltada para a exportação e alterou as relações sociais de produção consubstanciando-se na modernização conservadora da agricultura.

Com a implantação de indústrias de base (siderurgia, petroquímica etc.) as empresas produtoras de insumos, máquinas e equipamentos também se instalaram no país, internalizando a produção e, conseqüentemente, aumentando a capacidade de modernização da agricultura. Essas indústrias acabaram possibilitando a constituição a partir dos anos 70 os chamados Complexos Agroindustriais. Passa-se então a se exigir mais desenvolvimento tecnológico na agricultura, forçando a utilização de novas técnicas, justificando que a produção e o consumo de tecnologias modernas possibilitariam maior acumulação de capital. A modernização e industrialização que vai sendo incorporada a agricultura paulista e brasileira, no geral vão formar o proletariado do campo, restringindo a reprodução de formas independentes da pequena produção ou de formas em que o trabalhador mantém o controle do processo de trabalho. (Ibid. 2009, p.33)

Foi, portanto uma modernização considerada conservadora, pois expressa o discurso do moderno, sem, no entanto, mudar sua estrutura fundiária concentradora e excludente. 


\subsection{PRESSUPOSTOS E ORGANIZAÇÃO DO AGRONEGÓCIO CANAVIEIRO PARA O ESTADO DE SÃO PAULO}

Ainda de acordo com Soares Oliveira (2009) o Estado de São Paulo é propicio a expansão canavieira, pois possui condição edafo-climática favorável ao desenvolvimento da cana de açúcar, solo adequado à mecanização, logística e amplo mercado consumidor. Todavia, como o agronegócio canavieiro já se encontra consolidado nas áreas tradicionais, a expansão está para outras regiões não tradicionais no seu cultivo. Entre elas, estão as lavouras de laranja, como Araraquara (12 $\mathrm{RA})$ e de pastagens como São José do Rio Preto ( $\left.8^{\mathrm{a}} \mathrm{RA}\right)$,

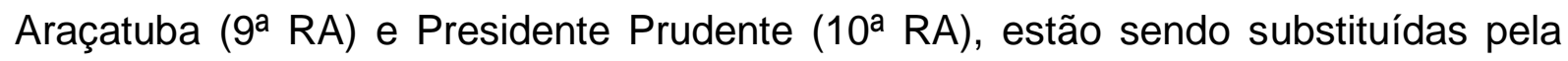
cana.

Cabe destacar em acréscimo que outros fatores também contribuíram para que ocorresse essa expansão para a porção Oeste do Estado de São Paulo. Assim como nas demais frentes de expansão, o aumento das vendas dos carros flex e a perspectiva de ampliação do comércio internacional do álcool combustível somaramse aos preços desfavoráveis praticados pela produção agropecuária, que atraíram os produtores para o sistema de fornecimento de cana-de-açúcar e, sobretudo de arrendamento das terras em detrimento da pecuária extensiva e, mesmo de atividades agrícolas.

Houve nos últimos anos uma evolução no preço da tonelada da cana, que em 2008 custava $R \$ 42,40$, passando a custar em $2012 R \$ 67,00$, um aumento de $36,7 \%$. Ao passo que a arroba do boi gordo foi comercializada a $R \$ 58,60 \mathrm{em} 2008 \mathrm{e}$ só agora obteve melhora na cotação, passando a custar $R \$ 93,00$ em 2012, um aumento de $37 \%$, mas depois de um período de quatro anos ${ }^{9}$.

A área plantada com cana de açúcar no Brasil evoluiu nos últimos anos, mesmo com a não renovação de muitos canaviais a partir de 2008 com a crise que eclodiu nos países centrais do sistema econômico, repercutindo no setor sucroalcooleiro nacional. No entanto, a safra no Centro Sul, particularmente no estado de São Paulo passou de 4.129,87 hectares na safra 2009/2010 para 4.357,01 hectares em 2010/2011, um aumento de 5,21\%.

\footnotetext{
${ }^{9}$ Ver mais em: http://www.ruralcentro.com.br/cotacoes
} 


\section{UM EXEMPLO PRÁTICO: O DESENVOLVIMENTO TERRITORIAL DO AGRONEGÓCIO CANAVIEIRO E SUA EXPANSÃO NO PONTAL DO PARANAPANEMA.}

Segundo Barreto (2009, p. 2) o processo de expansão da cana-de-açúcar na região do Pontal do Paranapanema vem legitimando o poder dos latifundiários, que ao longo do tempo utilizaram tanto a violência como de meios ilícitos para dominar este território e manter-se no poder. Sob o discurso do "bom negócio" e que tal atividade trará inúmeros benefícios para a região, tais como: geração de milhares de empregos, valorização das terras, e aquecimento da economia local/regional, levando consequentemente, a um maior crescimento econômico regional, é que em meio às lutas pelo direito a posse da terra e a produção de subsistência, contrapõem-se a oligarquia latifundiária, agora em aliança com o capital agroindustrial canavieiro.

O Pontal do Paranapanema contabiliza atualmente 09 unidades agroindustriais canavieiras e um projeto. São elas: Destilaria Alcídia S/A (ETH Bioenergia), no município de Teodoro Sampaio; Usina Alto Alegre S/A Açúcar e Álcool, no município de Presidente Prudente; Atena - Tecnologias em Energia Natural Ltda., em Martinópolis; Usina Alvorada do Oeste Ltda., em Santo Anastácio; Usina Cocal II - Cocal Comércio, Indústria Canaã de Açúcar e Álcool Ltda., em Narandiba; Decasa Destilaria de Álcool S/A, em Marabá Paulista; Destilaria Paranapanema Ltda., também em Narandiba; Paranapanema II - Destilaria Paranapanema S/A, em Sandovalina; Conquista do Pontal (ETH/Odebrecht) em Mirante do Paranapanema e o projeto Decasa II, em Presidente Epitácio.

Para entendermos um pouco melhor essa expansão da agroindústria canavieira no Pontal do Paranapanema, sobretudo o discurso que vem sendo utilizado para balizar novas instalações; selecionamos a Usina Alvorada do Oeste Ltda. no município de Santo Anastácio e a Destilaria Decasa, judicialmente declarada em território do município de Marabá Paulista e não mais em Caiuá. Analisando os principais aspectos do processo expansionista e de ampliação dos negócios das referidas empresas e mais especificamente a influência ideológica exercida por meio do discurso de geração de empregos, desdobramentos sociais, econômicos e ambientais delas em suas áreas de abrangência. 
Figura 1. Localização da Area de Estudo.

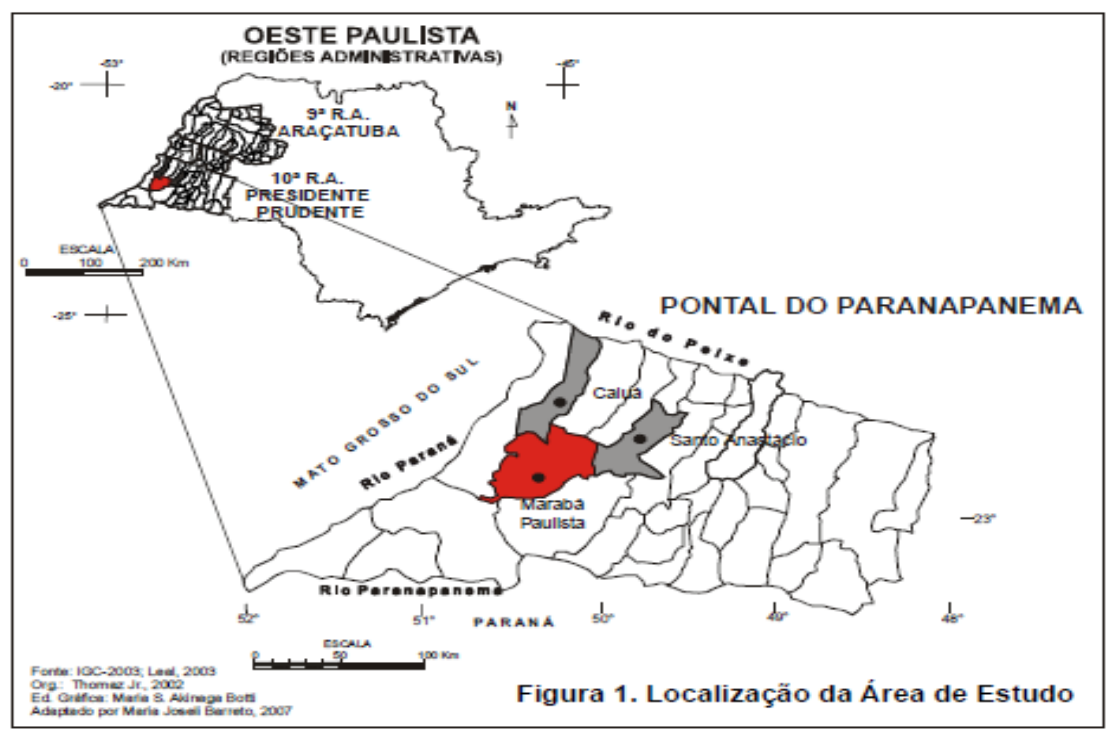

A região do Pontal do Paranapanema é conhecida, principalmente pelo conflito de terras, oriundas do grande grilo da Fazenda Pirapó - Santo Anastácio. Há uma disputa entre os movimentos sociais como o MST (Movimento dos Trabalhadores Rurais Sem Terra), o MAST (Movimento dos Agricultores Sem Terra), os grileiros e a UDR pelo direito a posse da terra, que se encontra concentrada nas mãos de poucos latifundiários por meio da prática ilegal da grilagem. (BARRETO, M.J.; THOMAZ JÚNIOR, A.; OLIVEIRA, A. M. S. 2009, p.13)

Esse panorama de concentração sempre foi visto como responsável pela grande desigualdade social presente na região, o que leva a população a reclamar do alto índice de desemprego, forçando a migração de jovens a procura de oportunidades de trabalho. Acarretando decréscimo nas populações municipais, o que diminui o Fundo de Participação dos Municípios; é nesse cenário precário que o capital sucroalcooleiro vem se apropriando para se instalar, inserindo a região no circuito do etanol.

No município de Santo Anastácio, onde se encontra instalada a agroindústria canavieira Alvorada do Oeste, a população não se demonstra preocupada com a possibilidade da expansão da cana-de-açúcar afetar a produção de alimentos, afirmam que o país possui muitas terras que podem ser utilizadas para produção de gêneros alimentícios, ainda afirmam que esta lavoura avança somente em áreas de 
pastagens degradadas. No que se refere à Destilaria Decasa, a população do município de Caiuá ${ }^{10}$ revela preocupação com a expansão da cana-de-açúcar sobre as terras agricultáveis, se expandindo inclusive para as pequenas propriedades produtoras de alimentos. (Ibid., p.11)

Há ainda a disputa pela comprovação da localização da Decasa Destilaria de Álcool S/A entre o município de Caiuá e Marabá Paulista, que sob o discurso da geração de empregos e renda para os municípios provocou uma "batalha judicial" de cinco anos.

Com o discurso da geração de novos postos de trabalhos, a destilaria Decasa, como representante do capital sucroalcooleiro, vem se aproveitando da disputa travada entre os municípios de Marabá Paulista e Caiuá, para solicitar a um e a outro, "isenção fiscal" e "benefícios", em troca de arregimento de mão-de-obra no município, aquisições no comércio local, pagamento de impostos e outros. O capital sucroalcooleiro diante da contenda aproximou-se do município de Caiuá, visando auferir uma série de benefícios para permanecer contribuindo com impostos, contratando trabalhadores e comprando no município. Entre os benefícios solicitados estão, à construção de casas populares para seus trabalhadores migrantes, melhorias nas estradas, entre outros. No entanto, tais pedidos não foram aceitos em virtude dos problemas políticos e econômicos que o município enfrentava no momento, com a cassação do prefeito Paulo Sergio Pinto de Souza e seu vice. Ante a recusa desse município, o empresário da agroindústria procurou o Poder Público do município de Marabá Paulista, solicitando tais benefícios, em troca do pagamento de impostos como IPVA, contratação de trabalhadores no município entre outros. (BARRETO, M.J.; THOMAZ JÚNIOR, A.; OLIVEIRA, A.M.S.; 2009 p.14-15)

Nesse cenário de expansão do capital sucroalcooleiro na região do Pontal do Paranapanema, portanto, disputas que vão além das disputas territoriais entre grupos sociais e latifundiários, ou entre o agronegócio e a produção camponesa. 0 capital também articula disputas intermunicipais que vão além do limite geográfico, como no caso apresentado entre os municípios de Caiuá e Marabá Paulista.

\section{AFINAL QUE DESENVOLVIMENTO TERRITORIAL É ESSE?}

As questões aqui levantadas a respeito do discurso de desenvolvimento territorial, pensado pelas entidades que representam o agronegócio nos permite afirmar que somente as grandes corporações se beneficiam deste modelo, a participação deste setor na produção do PIB nacional não é tão impactante como

\footnotetext{
${ }^{10}$ Na ocasião da pesquisa dos autores, a Destilaria Decasa S/A ainda se encontrava registrada no município de Caiuá.
} 
ressaltado pelos veículos propagandistas, revelando inconsistências nas informações que são apresentadas à sociedade.

No Brasil, a agricultura familiar sempre foi um setor marginalizado. Tal situação é fruto tanto da herança colonial do país, como do processo de "modernização desigual" da agricultura brasileira. Os grandes e médios produtores patronais ligados ao setor exportador, localizados fundamentalmente nas regiões Sul e Sudeste, foram os verdadeiros beneficiários dos estímulos governamentais para o meio rural. No modelo de desenvolvimento agrícola adotado no Brasil, preferiu-se impedir que suas populações rurais tivessem acesso à propriedade da terra, esse modelo patronal não foi o que prevaleceu em países desenvolvidos, como os Estados Unidos. (COSTA; RIMKUS; REYDON, 2008, p.02).

Diante desse quadro de tratamento diferencial aos agricultores familiares e aos representantes do agronegócio, as desigualdades no acesso às tecnologias distanciam ainda mais essas duas formas de atividade no campo. Assim para a agricultura familiar se faz fundamental o papel das políticas públicas, que possibilitam a geração de renda e a permanência desses agricultores e suas famílias no campo. Um dos exemplos mais recentes e que vem mostrando resultados positivos são os programas de compra de alimentos da agricultura familiar como o Programa de Aquisição de Alimentos (PAA) e o Programa Nacional de Alimentação Escolar (PNAE), garantindo renda e fortalecendo a organização de agricultores em associações.

O modelo sustentado no agronegócio também tem suas fragilidades como nos apontam Cavalcante e Fernandes (2008) às crises setoriais e globais que a humanidade passa já são alerta da insustentabilidade desse modelo de desenvolvimento. Desde empresas de porte internacional, até nações inteiras, ingressam em crises históricas.

Nos setores produtivos da agricultura capitalista tal fato não ocorre diferentemente; crises cíclicas do sistema financeiro ocorrem periodicamente levando muitos produtores à falência. Trata-se de um sistema extremamente "melindroso". A agricultura, por sua vez, sofre inúmeras alterações negativas mediante problemas ambientais, expansão de safras desproporcionalmente ao consumo mundial, decisões políticas que influenciam a mercantilização, problemas logísticos etc. Neste sentido, quando tratamos de um modelo de desenvolvimento 
agrícola monopolizador de terras, riquezas e, até mesmo, de funções sociais em um território, vislumbramos um perigoso arsenal produtivo devido sua inconstância diante das alterações conjunturais do sistema financeiro e das decisões políticas empresariais e do Estado.

\section{CONSIDERAÇÕES FINAIS}

Cabe-nos salientar que este modelo global imposto para o desenvolvimento territorial rural é bem sucedido na perspectiva do agronegócio, essa territorialização do capital através da industrialização da agricultura, também desigual no campo brasileiro, revela que o capitalismo unificou o que ele separou no início do seu desenvolvimento: indústria e agricultura. (OLIVEIRA, 1994, p. 51). Essa unificação ocorre porque o capitalista se tornou proprietário das terras, latifundiário, portanto.

O discurso do agronegócio é ideológico, escora-se na fragilidade das políticas públicas que pensam o campo, descrevendo a exportação e o que chamam de capacidade ou "vocação" do Brasil para a produção agrícola como algo positivo, já que gostam de apresentar números da balança comercial. Mas este discurso nada tem de bem comum, o que interessa ao grande capital é a lucratividade de suas atividades, sua lógica é produtiva, para tanto constroem, reconstroem, expropriam e se apropriam de conhecimento cientifico.

Resta-nos pensar em formas tão eficazes quanto aquelas que o grande capital adota para melhorarmos a qualidade de vida no campo, buscando junto aos agentes ali inseridos ou que nele pretendem se inserir, uma forma de resistir aos ataques e bombardeios desse modelo à pequena propriedade representada pela agricultura familiar.

\section{REFERÊNCIAS BIBLIOGRÁFICAS}

ABRAMOVAY, Ricardo. Paradigmas do capitalismo agrário em questão. São Paulo: HUCITEC, 1992.

BARRETO, M.J.; THOMAZ JÚNIOR, A.; OLIVEIRA, A. M. S. O discurso ideológico do agronegócio e a expansão do capital sucroalcooleiro na região do Pontal do Paranapanema. In: XIX ENCONTRO NACIONAL DE GEOGRÁFIA AGRÁRIA, 19. , São Paulo, 2009, p.1-22. 
BEZERRA, J.E. Agronegócio e ideologia: contribuições teóricas. Rev. Nera, Presidente Prudente, v. 12, n.13, p. 112-124, jul.-dez. 2009.

CAVALCANTE, M.; FERNANDES, B.M. Territorialização do agronegócio e concentração fundiária. Rev. Nera, Presidente Prudente, v. 11, n. 13, p.16-25, jul.dez. 2008.

Confederação Nacional da Agricultura e Pecuária do Brasil. 2011. Disponível em:< http://www.canaldoprodutor.com.br/sobre-sistema-cna/sistema-cna> Acesso em: 15 abr.2011.

CONGRESSO BRASILEIRO DE AGROBUSINESS, 9. , 2010, São Paulo. Anais... Dossiê: Cenários 2011 Comunicação e Governança: ABAG, 2011. 34 p.

Conselho Nacional do Café. 2011. Disponível em:< http://www.cncafe.com.br/galeria/00000191_ESTATUTO\%20CNC. doc> Acesso em 26 mai.2011.

COSTA, J.P.; RIMKUS, L.M.; REYDON, B.P. Agricultura familiar, tentativas e estratégias Para assegurar um mercado e uma renda. In: SOCIEDADE BRASILEIRA DE ECONOMIA, ADMINISTRAÇÃO E SOCIOLOGIA RURAL SOBER, 2008.

DENARDI, R. A. (2001). Agricultura Familiar e Políticas Públicas: alguns dilemas e desafios para o desenvolvimento rural sustentável. Agroecologia e Desenvolvimento

Rural Sustentável. Porto Alegre, v. 2, no 3 jul/set.

DOURADO, J.A.L; MESQUITA, H.A. Expropriação camponesa, agronegócio e precarização do trabalho em Livramento de Nossa Senhora (BA). Rev. Ideas, Rio de Janeiro, v.4, n. 1, p. 291-311, jun.-jul. 2010.

FELICIO, M.J. A conflitualidade dos paradigmas da questão Agrária e do capitalismo agrário a partir dos conceitos de agricultor familiar e de camponês. Rev. Campo - Território: revista de geografia agrária, Uberlândia, v. 1, n. 2 , p. $14-30$ ago. 2006.

FERNANDES, B. M. Agronegócio e Reforma Agrária. - Universidade Estadual Paulista. Pesquisador do CNPq - bmf@prudente.unesp.br Disponível em: $<$ http:www4.fct.unesp.brneratelaspubliacoesdonera.htm>. (s.d.). Acesso em: $12 / 05 / 2011$.

FERRARO, M. R. A gênese da agricultura e da silvicultura moderna no Estado de São Paulo. 2005. 120 f. Dissertação (Mestrado em Recursos Florestais, com opção em conservação de ecossistemas florestais) - Escola Superior de Agricultura "Luiz de Queiroz", Universidade de São Paulo, Piracicaba.

FREITAS, J.C.P. O negócio do agronegócio familiar. Portal do Agronegócio. 


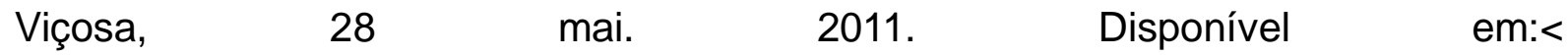
http://www.portaldoagronegocio.com.br/conteudo.

php?tit=0_negocio_do_agronegocio_familiar\&id=25012> Acesso em:28 mai.2011.

GUALDA, N. L. P. Agricultura familiar versus modelo agro-exportador: o falso dilema da não coexistência. In: SOCIEDADE BRASILEIRA DE ECONOMIA, ADMINISTRAÇÃO E SOCIOLOGIA RURAL - SOBER. 46. , 2008, Rio Branco. Anais... Amazônia, mudanças globais e agronegócios: $O$ desenvolvimento em questão. 2009. p. 1-15.

IGLÉCIAS, W. O empresariado do agronegócio no Brasil: ação coletiva e formas de atuação política - as batalhas do açúcar e do algodão na OMC. Rev. Sociologia Política, Curitiba, n.28, p.75-95, jun. 2007.

KAUTSKY, Karl. A questão agrária. Tradução de Otto E.W. Maas. Rio de Janeiro: Laemmert, 1986.

Ministério da Agricultura Pecuária e Abastecimento. Brasília: 2011. Site oficial do ministério. Disponível em:< http://www.agricultura.gov.br/ministerio> Acesso em: 25 mar.2011.

OLIVEIRA, A. M. S. Reordenamento territorial e produtivo do agronegócio canavieiro no Brasil e os desdobramentos para o trabalho. 2009. $571 \mathrm{f}$. Tese (Doutorado em Geografia) - Faculdade de Ciência e Tecnologia, Universidade Estadual Paulista, Presidente Prudente.

OLIVEIRA, A.U.; STEDILE. J. P. A cartilha: A natureza do agronegócio no Brasil. Fórum Nacional de Reforma Agrária. Brasília - DF. 2005.

OLIVEIRA, A. U. O campo brasileiro no final dos anos 80 . In: STEDILE, J.P.A Questão Agrária hoje. 2. ed. Porto Alegre: Editora da UFRGS, 1994. p.45-67.

PADILHA JÚNIOR, J.B. Agronegócios. In: UNIVERSIDADE FEDERAL DO PARANÁ. 2006. 12 p.

União da Indústria de Cana-de-açúcar. 2011. Disponível em< http://www.unica.com.br/content/show.asp?> Acesso em 26 mai. 2011.

União Democrática $\quad$ Ruralista. $2011 . \quad$ Disponível em:< http://www.udr.org.br/objetivos.htm> Acesso em: 26 mai.2011.

VEIGA, J. E. (1998), Diretrizes para uma nova política agrária. Anais do Seminário sobre Reforma Agrária e Desenvolvimento Sustentável. Fortaleza. Disponível em: www.nead.org.br.

(Recebido em: 21/02/2012. Aceito em 16/08/2012). 